Paper

\title{
New dye adsorption method for dye-sensitized solar cell utilizing electrostatic inkjet \\ 静電インクジェットを利用した色素増感型太陽電池の新しい色素吸着法
}

\author{
Shigeto KAWATA, Masafumi OGAWA, Yuki SHIMOYAMA, Shinjiro UMEZU, Yoshihito \\ KUNUGI \\ School of Engineering, Tokai University, Kitakaname 4-1-1, Hiratsuka-city, Kanagawa,259-1292 \\ Japan \\ TEL: +81-463-58-1211 e-mail: 3BMKM013@mail.tokai-u.jp \\ Hitoshi OHMORI \\ Institute of Physical and Chemical Research (RIKEN), Wako-shi, Saitama 351-0198, Japan \\ TEL: +81-48-462-1111 FAX: +81-48-462-1554 \\ (Received 6 March, $2014 \quad$ Accepted 28 November, 2014)
}

The Dye-Sensitized Solar Cell (DSC) has been attracting the attention of many researchers due to its good characteristics such as low cost, flexibility, and colorful panel. Normally DSC is produced by dipping a titaniacoated FTO electrode in the dye solution for over three hours to adsorb dye onto the titania layer of the DSC. We have been investigating fundamental characteristics of the electrostatic inkjet. Ejected droplets are charged because of high voltage application. Since the dye adsorption process depends on charge, charged dye gives a preferable effect to the adsorption process to shorten the adsorption time. In this study, an experimental set-up of an electrostatic inkjet was constructed to print dye on a titania-coated FTO electrode. We have investigated the fundamental characteristics of the dye-printed DSC by changing the printing time. As a result, the printing time was drastically reduced from several hours to about 14 or 15 minutes, and the efficiency proved to be about $5 \%$, which is a comparable value to that made by ordinary production methods.

Keywords : DSC, Dye adsorption, Micro digital fabrication, Production process

\section{INTRODUCTION}

近年，持続可能な社会実現のための様々なグリーンテ クノロジーが注目されている，太陽光をエネルギーに変 換する太陽電池もその中の一つである. 本研究では色素 増感型太陽電地 ${ }^{1-4}$ を対象として取り扱う. 色素増感型太 陽電池は低コスト, フレキシブル, カラフルという他の 太陽電池には無い特長を有し, 今後の需要が期待される. 普及にあたっては, 簡便で高精度な製造方法の確立が重 要となる. 色素増感型太陽電池の作製時のポイントとし て, チタニアの膜厚の精密制御技術, 色素の吸着時間短 縮技術 $^{5}$ が挙げられる. チタニアの膜厚は, 薄すぎると

SAS Award was given to this paper presented as Poster Presentation at the 2013 SAS Intelligent Symposium.
外部から入射した光が透過してしまい, 十分に光を吸収 することができない，一方，膜厚が厚すぎると電気抵抗 が増加し, 変換効率が低下してしまう。ゆえに膜厚の精 密制御技術が必要となる。また，色素の吸着時間は現状 では 3 時間以上を要している。これは，色素とチタニア がエステル結合するのに要する時間であり，製造時には この工程の短縮が重要である.

本研究室では静電インクジェット ${ }^{6-10}$ を利用すること で，チタニアの膜を作製できること，精密な膜厚制御に よって製造方法による変換効率向上が可能なことを把握 している. ${ }^{11}$ 静電インクジェットは, プリントされる液 体に高電圧を印加することで, 対象物へのプリントが行 われる。この際にプリントされる液滴は帯電した状態と なる。この特性を利用することで, 色素がチタニアへ吸 
着する際のエステル結合による電子の授受に対し, 電気 的補助を加える状態となり, 色素とチタニアが引付け合 い，吸着時間が短縮できるのではないかと予想した．本 論文では静電インクジェットを利用してチタニア膜へ色 素溶液をプリントし，短時間での吸着が可能であるかを 調べ，同方法によって作製された電池の変換効率の測定 を行った。

\section{DIP COATING WITH APPLIED VOLTAGE}

通常のディップコートの際に電圧を印加することで, 色素の吸着時間が短縮されるかを調べるための実験を行 った．Fig. 1 に後述するチタニアペーストをプリントし た色素増感型太陽電池の基板と, 色素溶液を満たした容 器を示す．透明電極（FTO コート基板）に対して静電イ ンクジェットを利用してチタニアペーストを $5 \mathrm{~mm}$ 角, 膜厚 $45 \mu \mathrm{m}$ 前後になるようプリントしたものを 6 素子用 意し, 非電圧印加のディップコートを施す 3 素子と電圧 印加を併用した 3 素子で吸着時間を 5 分に設定し比較を 行った.チタニアペーストはスクリュー管瓶に粒径 $21 \mathrm{~nm}$ のチタニア粒子（1.85g） と蒸留水（1.0g）を秤量し，ア セチルアセトン $(0.2 \mathrm{ml})$ ， ポリオキシエチレンオクチル フェニルエーテル $(1.0 \mathrm{ml})$, ポリエチレングリコール $(0.185 \mathrm{~g})$ の順に混合し, 䚓拌機を用いて攪拌, 脱泡した。 最後に, 超音波洗浄機を用いて超音波攪挥寸ることで作 製した. 色素溶液は, ルテニウム錯体(N719)0.0178g をア セトニトリルと $\mathrm{t}$-ブチルアルコールの 1:1 の混合溶液 $30 \mathrm{ml}$ に薄めて $0.5 \mathrm{~mol} \mathrm{l}^{-1}$ に調製したものである. 電圧印 加時の回路の模式図を Fig. 2 に示寸，電圧は直流 $15 \mathrm{~V}$ の 電源より印加される。作製された色素増感型太陽電池の 測定結果を Fig. 3 と Table 1 に示寸. 非電圧印加時のサン プルが約 $4.0 \% の$ 変換効率であったのに対し, 電圧印加時 のサンプルは 2 つのサンプルが $1 \%$ 未満の值, 残り 1 サ ンプルも $1.2 \%$ に留まった. 電圧印加中に溶液中から色素 が分離し,負極周辺に集中寸る状態が観察されたことか ら, 通常のディップコート時の電圧印加では色素吸着に 好影響を与えることができなかった。
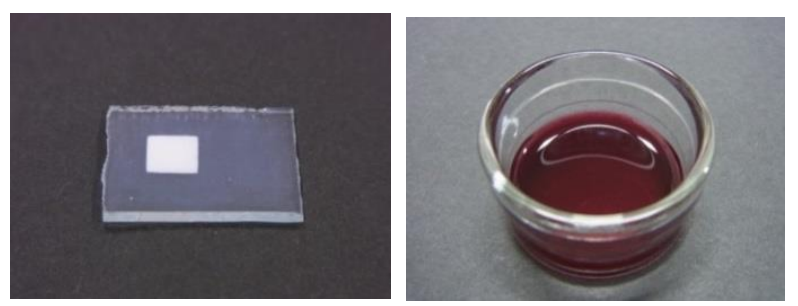

Fig. 1. The cell (before dye adsorption) and dye solution.

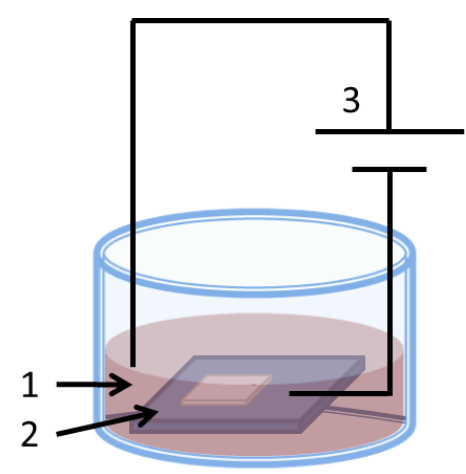

Fig. 2. Dip coating with applied voltage. (1: Dye solution, 2: titania coated FTO electrode, 3: voltage power supply)

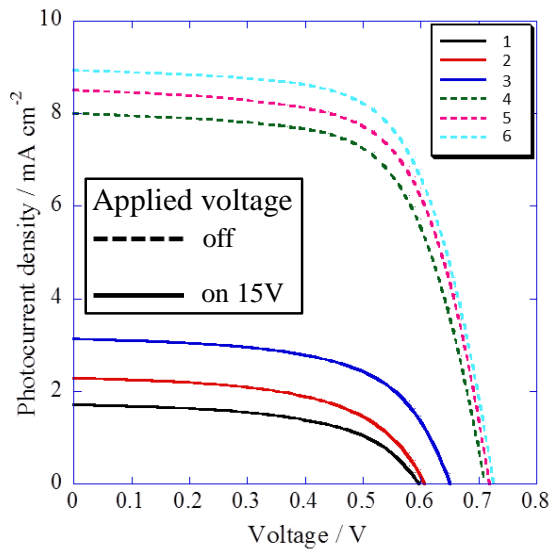

Fig. 3. $J-V$ curves of dye-sensitized solar cell. The number in legend corresponds with the sample name of table 1.

Table 1. Specifications of fabricated DSCs.

\begin{tabular}{ccccccccc}
\hline Sample name & $\begin{array}{c}\text { Voltage Thickness } \\
/ \mathrm{V}\end{array}$ & $\begin{array}{c}J_{\mathrm{sc}} \\
/ \mu \mathrm{m}\end{array}$ & $\begin{array}{c}V_{\mathrm{oc}} \\
\mathrm{mA} \mathrm{cm}\end{array}$ & $\begin{array}{c}\eta \\
/ \mathrm{V}\end{array}$ & $\begin{array}{c}R s \\
/ \%\end{array}$ & \multicolumn{2}{l}{$\Omega$} \\
\hline 1 & 15 & 47.40 & 1.71 & 0.6 & 0.56 & 0.57 & 178 \\
2 & 15 & 52.44 & 2.29 & 0.61 & 0.56 & 0.79 & 140 \\
3 & 15 & 49.41 & 3.13 & 0.66 & 0.60 & 1.20 & 90 \\
\hline 4 & - & 49.41 & 8.00 & 0.71 & 0.66 & 3.70 & 56 \\
5 & - & 48.31 & 8.51 & 0.72 & 0.66 & 4.00 & 49 \\
6 & - & 46.38 & 8.93 & 0.73 & 0.66 & 4.30 & 50 \\
\hline
\end{tabular}

\section{EXPERIMENTAL SET-UP}

静電インクジェットを利用した色素プリント時の装置 構成を Fig. 4 に示す．吐出対象にはディップコートの際 と同様のチタニアペーストをプリントした FTO 基板を 用い，使用した色素溶液もディップコートの際と同様で ある. テルモ社製注射器シリンジ(SS-10SZ)の先端にサン エイテック社のノズル $(\mathrm{SH} 30-0.25-\mathrm{B})$ を取り付け，シリン ジの $2 \mathrm{ml}$ のメモリまで色素溶液を満たした。対象の FTO 基板は約 $25 \mathrm{~mm} \times 30 \mathrm{~mm} \times 2 \mathrm{~mm}$ とし， $230 \mathrm{~mm} \times 270 \mathrm{~mm} \times$ $1 \mathrm{~mm}$ のステンレス平板の中央にセットした. FTO 基板と 
ステンレス平板はアースに接続される構成とした. ステ ンレス平板はx-y リニアステージに設置され, PCによっ てコントロールされる.ノズル先端と FTO 基板との GAP を $5 \mathrm{~mm}$ に設定し, 高電圧を印加することでプリントが 開始される. Fig.5 に示されているように, 色素溶液プリ ント開始時(a), 開始から 15 秒後(b), 30 秒後 (c)の様子 をそれぞれ示す．チタニア膜が徐々に赤く染まっている 様子が確認できる.また, 印加電圧を変化させることで, 吐出モードを変化させることができる. 本実験構成の場 合, $3 \mathrm{kV}$ ではノズル内径以下の大きさの液滴が FTO 基板 にプリントされるが (ドロップレットモード), 印加電圧 $4 \mathrm{kV}$ では帯電した液滴内での静電力による反発がより強 まり, FTO 基板にプリントされる前に, スプレー状に分 裂する (スプレーモード). チタニア膜に一様にプリント を行うため, スプレーモードを用いたが, 後述する色素 溶液の浸透が，電池特性に影響を与えることを判断す るため, ドロップレットモードによるプリントも行った.

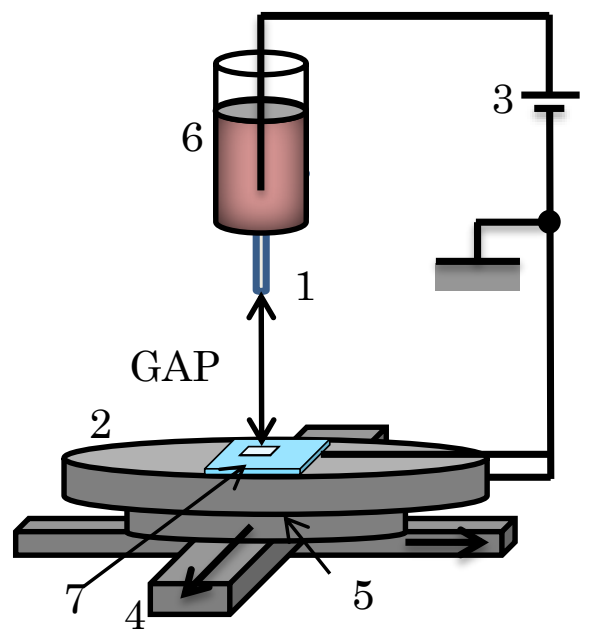

Fig. 4. Experimental set-up to investigate patterning characteristics. (1: Water pin electrode, capillary tube filled with dye solution, 2: plate electrode, 3 : high voltage power supply, 4: x-y linear stages, 5: mechanical z-stage, 6: syringe , 7: FTO glass)

\section{PRINTING DYE ON FTO ELECTRODE}

色素が短時間でチタニアに吸着することを確認するた め, 画像解析ソフト Image $\mathrm{J}$ を用いた観察を行った. デ イップコート時と同様の FTO 基板に $15 \mathrm{~mm} \times 20 \mathrm{~mm}$ の面 積で同様のチタニアペーストをプリントし, 吐出時間毎 に色素溶液を塗り分けるために $2 \mathrm{~mm} \times 15 \mathrm{~mm}$ のアルミ製 マスクを設置し, 色素溶液吐出時間を Fig. 6 のように左

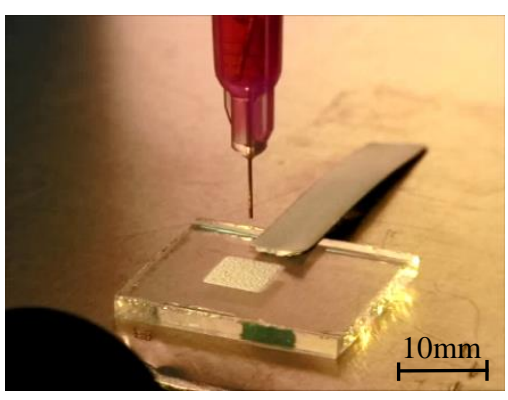

(a) Start of dye print

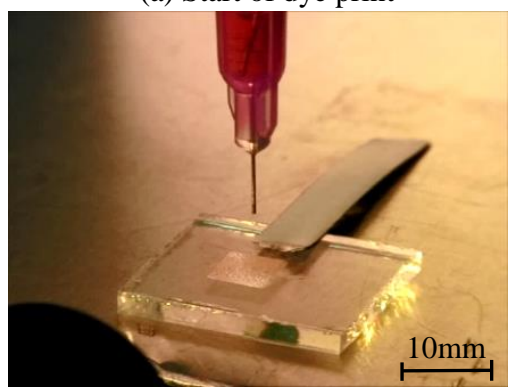

(b) Process of dye print, $15 \mathrm{~s}$

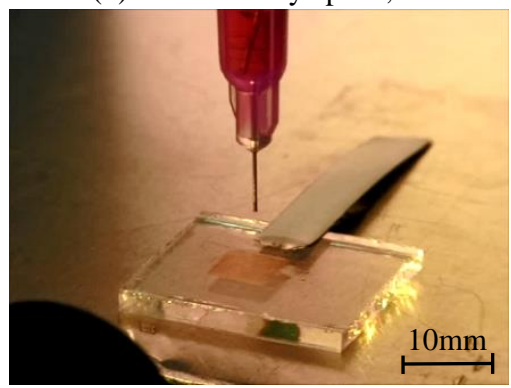

(c) Process of dye print, 30s

Fig. 5. Printing images.

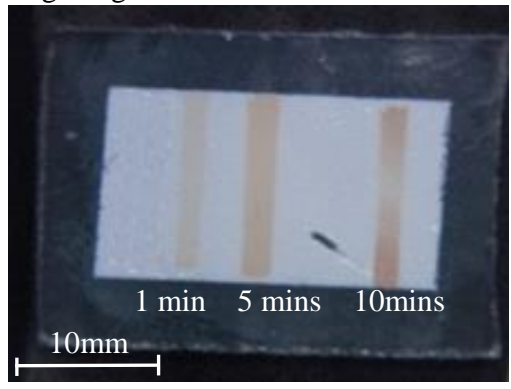

(a) Before rinse

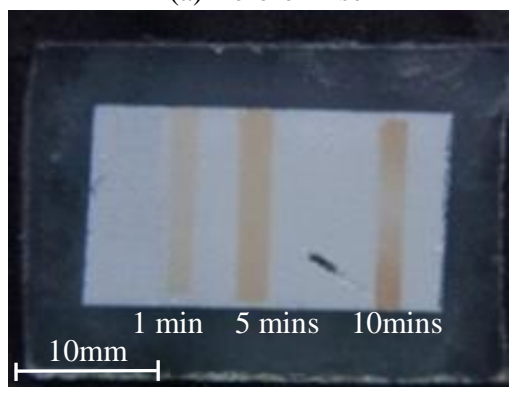

(b) After rinse

Fig. 6. Printed dye on sintered titania of FTO electrode when printing time is changed. Printing time of left, middle, and right are 1 min, 5 mins, and 10 mins, respectively. 
から 1 分, 5 分, 10 分に分けプリントした. チタニアに 付着した発電に寄与しない余分な色素を洗い落すため, アセトニトリルを用いたリンス作業を行った. リンス作 業後に余分な色素が洗い流された場合, 色合いがリンス 作業前後で変化する. そのため, リンス前後での色合い の変化を画像処理ソフト Image J にて比較した. 比較し た画像を Fig. 7 に示す. 上段がリンス前の状態, 下段が リンス後の状態であり, 吐出時間 1 分の状態で, プリン 卜前後での色合い変化が見られず, 色素の吸着が確認さ れた。

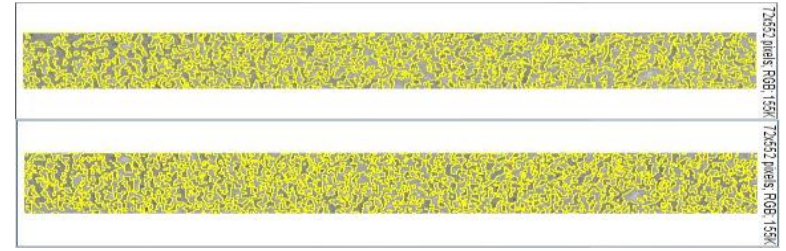

Fig. 7. Image analysis of printed dye on sintered titania. Upper image is dye before rinse, and lower image is dye after rinse.

\section{FABRICATION OF DSC}

印加電圧を $4 \mathrm{kV}$ ，ノズル先端と FTO 基板との GAP を $5 \mathrm{~mm}$ に設定し, 実際に色素増感型太陽電池の素子を作製 した. FTO 基板, チタニアペースト, 色素溶液はこれま での実験と同様のものを用いた。色素溶液プリント時間 を 1 分, 5 分, 10 分とし, プリント後の素子の表を(a), 裏を(b)として Fig. 8 に示寸. 使用した色素が吸着してい ないチタニアは発電に寄与しないため, 裏面までの色素 の浸透が必要である. Fig. 8 より, 色素溶液は表面だけで なく裏面へも浸透し，プリント時間が長くなるほど色が 濃くなっている. 比較として, 通常のディップコートに よって 3 時間色素溶液中に置かれた素子を Fig. 9 に示す. 裏面まで一様に色素溶液が浸透しているが, 静電イ

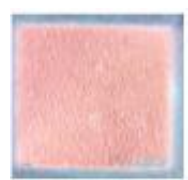

$1 \min$

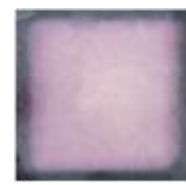

$1 \min$

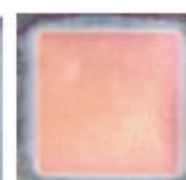

5 mins

(a) Frontside

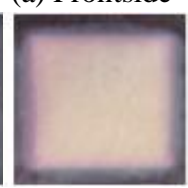

5 mins

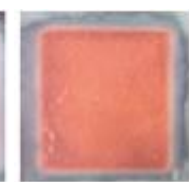

10 mins

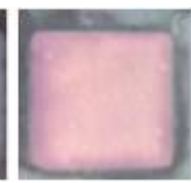

10 mins (b) Backside

Fig. 8. Printed dye of DSC after changing printing time. Printing time of each photograph is $1 \mathrm{~min}, 5 \mathrm{mins}$, and $10 \mathrm{mins}$.

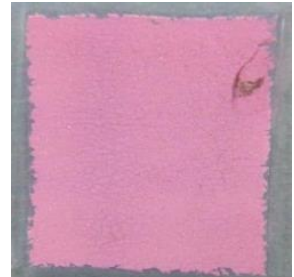

(a) Front side

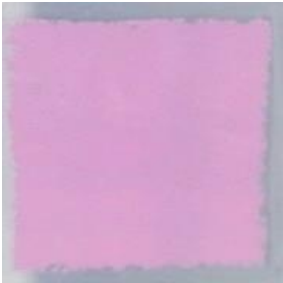

(b) Back side
Fig. 9. Dip-coated dye of DSC.

ンクジェットを利用した場合も，プリント時間のコント ロールによって可能といえる，作製された素子は，基準 原器であるソーラーシミュレータによって太陽電池特性 を測定した. Table 2 に静電インクジェットを利用して作 製されたサンプル素子の特性を示す. 各特性項目は，Jsc が短絡電流密度，Voc が開放電圧であり，それぞれ素子 が出せる最大電流を面積で割ったものと最大の電圧を示 している。ffはフィルファクターで, 最大発電電力と前 出二項目の積との比である. $\eta$ は変換効率, $R \mathrm{~s}$ は抵抗值 となっている. サンプル 1〜9 までが印加電圧 $4 \mathrm{kV}$ によ って色素プリントされたものである.サンプル 10〜12 は, 後述する吐出モードを変化させて作製したものである. 色素プリント時間 1 分のサンプルでは，色素吸着が不十 分なため, 5 分, 10 分のサンプルよりも変換効率が劣っ ている．プリント時間が伸びるにつれて変換効率が上昇 していることがわかるが，これはプリント時間が伸びる ことで，より長い時間チタニアが色素溶液にさらされる ことによる色素吸着量の増加のためと考えられる。しか し, サンプル5では5分のプリント時間にもかかわらず, 10 分のプリント時間のサンプルよりも高い変換効率と なった. サンプル 3 についても, サンプル 4,8 より高い 值となっている。 これは前述した色素溶液の浸透による もので，同じプリント時間内でもバラつきが生じている ためである，そのため，印加電圧を変更することで，

Table 2. Specifications of fabricated DSCs when the printing time of dye.

\begin{tabular}{cccccccc}
\hline Sample name & $\begin{array}{c}\text { Printing time } \\
/ \mathrm{min}\end{array}$ & $\begin{array}{c}\text { Thickness } \\
/ \mu \mathrm{m}\end{array}$ & $\begin{array}{c}J_{\mathrm{sc}} \\
/ \mathrm{mA} \mathrm{cm}\end{array}$ & $\begin{array}{c}V_{\text {oc }} \\
/ \mathrm{V}\end{array}$ & ff & $\begin{array}{c}\eta \\
/ \%\end{array}$ & $\begin{array}{c}R s \\
/ \Omega\end{array}$ \\
\hline 1 & 1 & 47.71 & 2.37 & 0.610 & 0.49 & 0.7 & 187.8 \\
2 & 1 & 46.64 & 4.87 & 0.656 & 0.58 & 1.9 & 86.7 \\
3 & 1 & 47.63 & 8.21 & 0.711 & 0.61 & 3.5 & 59.5 \\
\hline 4 & 5 & 49.49 & 6.20 & 0.674 & 0.65 & 2.7 & 61.6 \\
5 & 5 & 46.58 & 10.30 & 0.704 & 0.64 & 4.6 & 52.7 \\
6 & 5 & 43.85 & 8.86 & 0.713 & 0.65 & 4.1 & 52.7 \\
\hline 7 & 10 & 46.60 & 8.16 & 0.773 & 0.63 & 4.0 & 63.9 \\
8 & 10 & 47.75 & 8.71 & 0.697 & 0.52 & 3.2 & 94.5 \\
9 & 10 & 48.52 & 10.39 & 0.716 & 0.60 & 4.5 & 65.6 \\
\hline 10 & 5 & 46.68 & 11.10 & 0.725 & 0.63 & 5.1 & 55.7 \\
11 & 5 & 46.70 & 13.00 & 0.744 & 0.62 & 6.0 & 51.5 \\
12 & 5 & 47.73 & 14.40 & 0.750 & 0.60 & 6.5 & 53.4 \\
\hline
\end{tabular}


スプレーモードによってプリントされていた色素溶液を， ドロップレットモードによってプリントするように印加 電圧を変更することで, 液滴の大きさを大きくし, より 浸透しやすくする方法を試みた. 印加電圧 $4 \mathrm{kV}$ 時のスプ レーモード， $3 \mathrm{kV}$ 時のドロップレットモードそれぞれの 際のノズル先端の様子を Fig. 10 に示す. 上段の $4 \mathrm{kV}$ 時 には色素溶液がノズル先端からスプレー状に広がるのに 対し， $3 \mathrm{kV}$ 時には大きな液滴となってプリントされてい ることが確認できる. また, それぞれのモードの際の素 子上のプリント領域を Fig. 11 に示す. スプレーモード時 には酸化チタン上を同時にプリントしていたが，ドロッ プレットモードでは領域が減少するため, $\mathrm{x}-\mathrm{y}$ ステージ をコントロールすることでつづらおり状の経路とし， 5 分間プリントを行った. その際のプリントの様子を Fig. 12 に示す. それぞれ, 色素溶液プリント開始時(a), 開始 から 15 秒後(b), 30 秒後(c)の様子であり, 手前から奥へ 向かって徐々に色が濃くなっていることが確認できる. この方法によって作製された素子サンプルが Table 2 の サンプル 10〜12 である. スプレー状にプリントしたサ ンプルよりも高い変換効率となった. 色素溶液がより浸 透しやすくなったためと考えられる. 最高の $6.5 \%$ の変換 効率については, 通常のディップコートで 3 時間浸漬さ せた素子と同等の変換効率と言える. 本論文で作製され た素子を, 横軸に色素溶液プリント時間, 縦軸に変換効 率としてまとめたものを Fig. 13 に示す. 三角プロットが ドロップレットモードでプリントされたサンプルである.

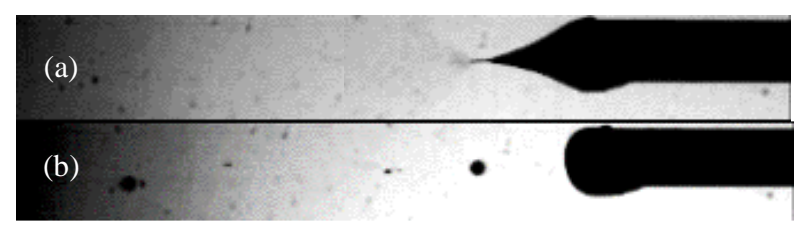

Fig. 10. Images of nozzle tips for both types of printing: (a) spraying and (b) droplet mode.

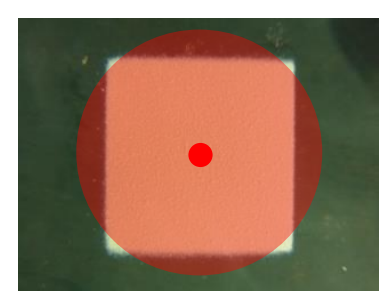

(a) Spray mode

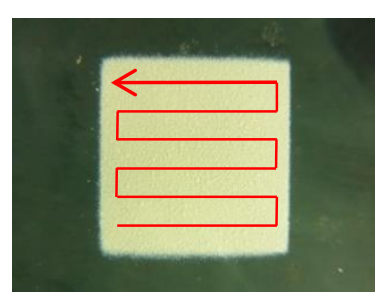

(b) Droplet mode
Fig. 11. Images of nozzle position when printing dye solution. (a) Center circle is nozzle position. Outer circle is sprayed area. (b) Arrow is nozzle path.

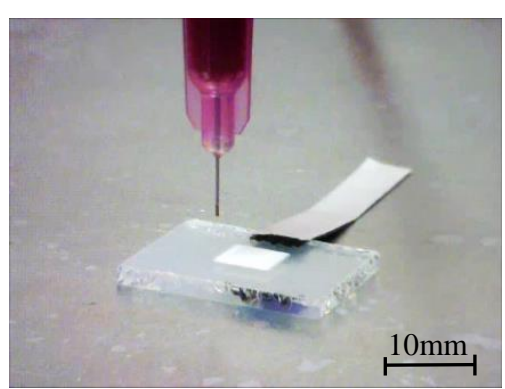

(a) Start of dye print

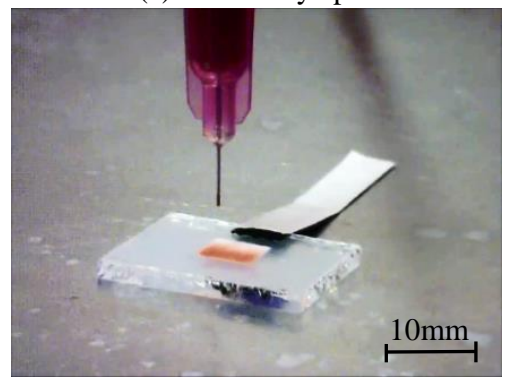

(b) Process of dye print, $15 \mathrm{~s}$

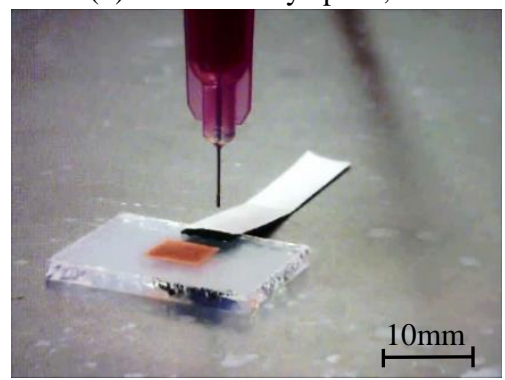

(c) Process of dye print, $30 \mathrm{~s}$

Fig. 12. Printing images when tip of nozzle is moving from front to back. Color gradually becomes darker.

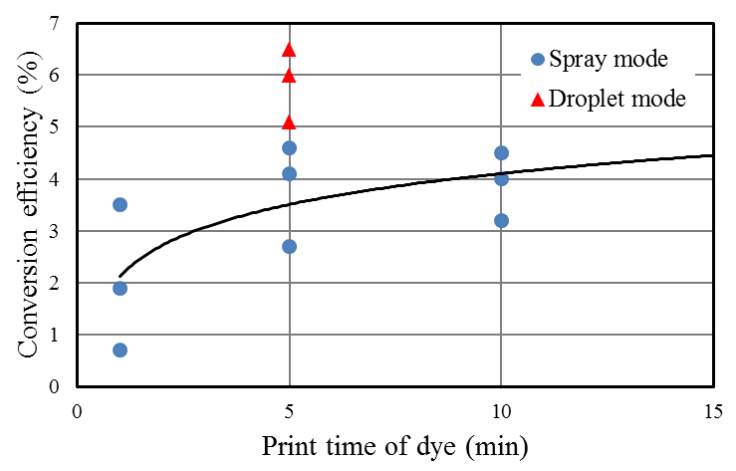

Fig. 13. Efficiency of fabricated DSCs when time to print dye is changed.

\section{CONCLUSION}

色素増感型太陽電池の色素吸着工程に対して, 静電イ ンクジェットを適用可能なことが示された。印加電圧を コントロールすることで吐出モードを変化させ, 色素溶 液を浸透させることで, 色素溶液プリント時間 5 分にお 
いて約 5\%の変換効率を実現した。 通常のディップコー トによる 3 時間の色素吸着工程と同等の変換効率であり, 色素吸着時間が短縮可能であることが示された.

\section{ACKNOWLEDGEMENTS}

本研究は, 「科研費基盤 (C)」及び東海大学総研プロ ジェクト「二酸化チタン層の精密制御による色素増感型 太陽電池の高機能化」の助成を受けました，謝意を表し ます。

\section{REFERENCES}

1 B. O'Regan, M. Grätzel, Nature, 353, 737-740 (1991).

2 A. Hagfeldt and M. Grätzel, Acc. Chem. Res., 33, 269-277 (2000).

3 H. Arakawa, J. Surface Finish Soc. Jpn.,59. 167 (2008) (in Japanese).

4 S. Ferrere, B. A. Gregg, J. Phys. Chem. B105, 7602-7605 (2001).
5 B. Kim, S. W. Park, Jae-Yup Kim, K. Yoo, J. A. Lee, Min-Woo Lee, Doh-Kwon Lee, J. Y. Kim, BongSoo Kim, H. Kim, S. Han, H. J. Son, and M. J. Ko, Appl. Mater. Interfaces, 5, 5201-5207 (2013).

6 M. M. Mohebi and J. R. G. Evans, J. C. Chem, 4, 267-274 (2002).

7 D. Jang, D. Kim and J. Moon, Langmuir, 25, 2629- 2635 (2009).

8 C. Yang, E. Zhou, S. Miyanishi, K. Hashimoto and K. Tajima, ACSAppl. Mater. Interfaces, 3, 4053-4058 (2011).

9 Y. Zhang, S. Yang, L. Chen and J. R. G. Evans Langmuir, 24, 3752-3758 (2008).

10 S. J. Kim, Y. A. Song, P. L. Skipper and J. Han, Anal. Chem, 78, 8011-8019 (2006).

11 S. Umezu, Y. Kunugi, and H. Ohmori, Jpn. J. Appl. Phys. 52, 05DC23 (2013). 